\section{Examination of The Students' Mistakes of Oral Reading}

\author{
Murat Başar ${ }^{\mathrm{a},{ }^{*}}$, Zekerya Batur ${ }^{\mathrm{b}}$
}

$\begin{array}{ll}\text { Received: } & 14 \text { August } 2018 \\ \text { Revised: } & 11 \text { November } 2018 \\ \text { Accepted: } & 20 \text { October } 2018 \\ \text { ISSN: 1307-9298 } \\ \text { Copyright } \odot \text { IEJEE } \\ \text { www.iejee.com }\end{array}$

DOI: 10.26822/iejee.2019248598

\begin{abstract}
In this study, it is aimed to examine the level of oral reading of the students studying on their $3^{\text {rd }}$ degree, who are at the age range of $60-66$ months, and the students who completed their $72^{\text {nd }}$ month and started primary school. The sample of the study is constituted of 100 students in the $3^{\text {rd }}$ grade who study in primary schools Usak city center. 51 of the students are between the age range of 60-66 months. 49 of the students were recorded to be 72-months old. As a result of the study, it has been identified that the students who started primary school between the age range of 60-66 months made the mistake of oral reading by omitting the syllable and adding the syllable rather than the students who had completed their $72^{\text {nd }}$ month. The students did not make the translation of the words at all. The students made the mistake of contemplating most at the level of concern. It was observed that starting the process of reading with open syllables decreased the mistakes of oral reading. It was determined that time dependent reading and emotional problems increase the mistakes of oral reading.
\end{abstract}

Keywords: Oral Reading, Oral Reading Mistakes, 60-66 Months-Old Students, 72 Months-Old Students

\section{Introduction}

Native language is an ability that a child acquires from her/ his guardian and environment (Yıldız \& Karataş, 2017; Sever, 2011). This ability is improved by acquiring the fields of listening, speaking, reading, writing and grammar fields actively. Especially the listening ability that contributes to the improvement of language both in an explicit and implicit way. (Emiroğlu, 2013). It is an ability that reveals what a student understands and strengthens the manner of expression. Reading involves a specific process. This process has multiple components and variables (Malu \& Mcneal, 2017; Özfidan, 2017; Yangın, 1999; Özdemir, 1987). In this process, mother, father, guardian, friend, teacher and generally environment can be effective. Before the pre-school period, family involvement affects the process of reading whereas friends and teachers affect it in educational terms.

Significantly the attitudes of the classroom teachers are of great importance in the first reading and writing period. The attitudes and behaviours of the classroom teachers during oral reading can affect the speed of oral reading and reading comprehension of the students (Topping, 2014; Allington, 2014; Paige \& Agpuri-Lavell, 2014). Time dependent competitions can be given as examples for the reason of the students to make reading mistakes during oral reading (Başar, Batur \& Karasu 2014). In time dependent reading, the students try to utter a word correctly if they are able to recognize the word, and try to make up a definition or skip it if they do not recognize the word. This case can cause the students to make different reading mistakes.

In the body of the literature conducted, it has been observed that there has only been a limited number of studies conducted regarding the students starting school between the age range of 60-66 months and their oral reading mistakes ( Bay \& Anılan, 2015; Susar Kırmızı, 2015; Işık, 2014; Başar, 2013). Duran (2013) examined the writing abilities of the students who started primary school on their $60^{\text {th }}$ month. It has been identified that the writing abilities of the students who started the school at the age range of 60-66 months were inadequate. Studies have been conducted on oral reading mistakes as well as the elimination of the mistakes. However, an applied and comparative study has not yet been found in the literature regarding the reasons of oral reading of both the students who start primary school between the ages of 60 and 66 months and the students who start primary school at the normal standard age. According to Begeney and Martens (2006), the studies on oral and silent reading should aim the enrichment of accurate vocabulary and improvement of voice recognition abilities as well as teaching the phenological features of language to first grade students in primary schools. In the second grade, studies should continue on the enrichment of vocabulary that the students have. Begeney and Martins stated that in the third grade, significant factors such as gradual acquisition of fluent reading abilities and the acquisition of the abilities of fast and accurate reading related to the text, accordingly, that the $3^{\text {rd }}$ grade should be a period in which fluent reading studies should be emphasized. It is stated that the studies aiming at the acquisition of fluent reading and reading comprehension should be implemented in the fourth and fifth grades. Another reason for selecting the third grades is due to that the fluent reading studies are focused in this period as it is stated above. From this aspect, it is believed that the study will make a paramount contribution to the field.

\section{Purpose}

Answers were sought for the following sub-problems in this study in which the examination of oral reading mistake levels of the students who start primary school at the age range of 60-66 months and in their normal age.

1. What is the frequency level of observing the oral reading mistakes of the third grade students in primary schools? 
2. Oral reading mistakes of the students are based on;

a. Starting age at primary school between the ages of 60-66 months and after completing the $72^{\text {nd }}$ month,

b. Gender,

c. Method of conducting the process of writing in primary school with open/closed syllable,

d. Status of students receiving support out of school hours,

e. Status of the classroom teachers receiving an expert consultancy in the period of the first reading and writing process,

f. Status of the students having emotional troubles,

\section{g. Status of time dependent oral reading,}

h. Duration of completing the first reading and writing periods,

i. Period of reading the text,

j. Does it become different according to the forming of the classrooms?

Method

This study is within the scope of the descriptive survey model since the purpose is to identify the present situation. Survey models are the approaches that aim to describe an event taken place in the past or which is still ongoing in its existing form. A matter, individual or object in the study are attempted to be identified within their own conditions as they exist. Efforts are not made to change or affect anything in any manner (Karasar, 2011).

\section{Population}

The population of the study is composed of $3^{\text {rd }}$ grade students who study in primary schools, subject to the Ministry of National Education, in Uşak province in the academic year of 2014-2015.

\section{Sample}

The sample of the study is composed of 100 students in the $3^{\text {rd }}$ grade who study in primary schools on each two schools that have low, intermediate and good socio-economic levels in Usak city center in the 2014-2015 academic year. In this way, maximum amount of variety has been provided. 57 of the students in the study are female and 43 of them are male who took part in the sample of the study. 51 of the students are between the age range of 60-66 months and 49 of whom are students who started the primary school at their normal standard age. 18 of the students took part with the students who are between the age range of 60-66 months and with the students who started the school at their normal age. 33 students continued to receive education only in the classroom with the students who are at the age range of 60-66 months. 44 of whom are students of the school having the low level of socio-economic environment, 21 of them are the students of the school having the intermediate level of socio-economic environment and 35 of them are the students of the school having the good level of socio-economic environment.

\section{Study Model and Data Collection Tool}

In the study, the model is based on the researcher, and the subject researched. The researcher selects the appropriate model in accordance with the subject in order to obtain reliable data related to the subject she/he will do research on. The appropriate model is significant for the study. The trial model has been used in the study due to its convenience. Trial models involve the production of the data that is desired to be observed under the control of the researcher with the purpose of identifying the cause-effect relationship (Karasar, 2011). According to Büyüköztürk et.al. (2010), survey researches are the studies which are generally conducted on larger samples compared to other studies, where features such as interest, ability, talent, attitude etc. of the participants on a certain subject or event are focused on. "Anatolia" piece which is composed of 184 words and 421 syllables has been selected as the data collection tool.

\section{Data Analysis}

The data of this study in which the oral reading mistake levels are aimed to be examined among the students who completed the age range of $60-66$ months as well as those who completed the $72^{\text {nd }}$ month then started the primary school and going on to the $3^{\text {rd }}$ grade, have been evaluated with the use of the SPSS program. Karasar (2011), in accordance with the objectives of the data research period, described the analysis of the data as determining the fundamental elements and features. Frequency and percentage tests have been implemented in order to identify the frequency of oral reading mistakes. Age range, gender, starting the first reading-writing process with open or closed syllable, the student's status on receiving external support, the classroom teachers' status of receiving consultancy, whether the classroom teachers have emotional problems and the differentiation depending on the status of time dependent reading have been evaluated with the $t$-test method. In order to determine the difference between the period of completing the first reading-writing process, duration of reading the text and the method of composing the classrooms, the ANOVA $(F)$ test has been implemented. Regression analysis has been conducted in order to identify the impact of the independent variables upon the dependant variable, and to determine the relationship between them.

\section{Implementation Process}

The children between the age range of $60-66$ months also started the school beginning from 2012-2013 academic year with the act that was published in the official newspaper dated July 20, 2012 and serial numbered 26263. The students who began the school on this date, had their $3^{\text {rd }}$ year of education as of 2014-2015 academic year. Some of these students received education in classrooms composed of students who started the primary school between the age range of 60-66 months, and some of them received coed-education with students who started the school at the normal standard age. Only the classrooms in which the students receiving education at the age range of 60-66 months have been identified in the primary schools in Usak city center. Interviews have been carried out with the teachers in these classrooms. The students volunteered to take part in the study, studying in the classrooms, as well as three volunteer classroom teachers who volunteered to take part in the study, have been included in the sample of the study. In the same way, other groups of students were also incorporated in the study using the same method. Throughout the study, attention was paid to the use of reading text which are not part of the syllabus across schools in Usak city center. In this context, "Anatolia" piece which is composed of 184 words and 421 syllables has been selected as the data collection tool. In the classrooms where the study was conducted, the teachers were asked whether or not the 
text was convenient, with a later result stated by teachers that it had relevance. Then, the views of three experts in the branches of classroom teaching and Turkish teaching for the convenience of the reading text were shared. The implementations were initiated after the experts had stated their opinions. The negotiations were made with the directors in the school and the students were asked to read out the text aloud after the relevant students were taken into a room individually. The students were not able to hear what other students said in the activity and they were enabled not to be distracted by each other. Two minutes of speech were made with the students in order for them not to be affected by the environment negatively. In this way, the necessary surrounding was established in order for students not to become apprehensive or shy. Mistake frequency of the students were identified by marking down each mistake that the students made, among the 18 oral reading mistakes that were determined in Başar, Batur and Karasu, (2014) study while the text was read out by the students. Another researcher followed the reading time of the student without being informed. In this way, it was desired to examine the impact of the student's time of reading the text upon the oral reading mistakes without creating pressure. Reading mistakes of the students were coded as free, acceptable and concern level. The coding was developed by the researchers by utilizing from "False Analysis Inventory" that was prepared by Akyol, (2012), Haris and Spay, (1990), Ekwal Shanker (1988) and May (1986). Some personal information of the independent variables of the study were collected from the teachers.

\section{Findings}

\section{Findings Related to the First Sub Problem}

Table 1. Percentage (\%) Frequency (f) Results of Oral Reading Mistakes

\begin{tabular}{|c|c|c|c|c|c|c|}
\hline $\begin{array}{l}\text { Oral Reading } \\
\text { Mistakes }\end{array}$ & $\begin{array}{c}\text { Free } \\
F\end{array}$ & $\%$ & $\begin{array}{c}\text { Acceptable } \\
f\end{array}$ & $\%$ & $\begin{array}{l}\text { Concern } \\
\text { Level } f\end{array}$ & $\%$ \\
\hline Repeating & 59 & 59 & 22 & 22 & 19 & 19 \\
\hline Contemplating & 38 & 38 & 24 & 24 & 38 & 38 \\
\hline Interruption & 77 & 77 & 18 & 18 & 5 & 5 \\
\hline $\begin{array}{l}\text { Omitting the } \\
\text { Syllable }\end{array}$ & 57 & 57 & 19 & 19 & 24 & 24 \\
\hline $\begin{array}{l}\text { Adding the } \\
\text { Syllable }\end{array}$ & 80 & 80 & 12 & 12 & 8 & 8 \\
\hline Mixing the Sounds & 97 & 97 & 3 & 3 & 0 & 0 \\
\hline Adding Sound & 90 & 90 & 8 & 8 & 2 & 2 \\
\hline $\begin{array}{l}\text { Not Being Able to } \\
\text { Control Breathing }\end{array}$ & 90 & 90 & 4 & 4 & 6 & 6 \\
\hline Skipping & 96 & 96 & 1 & 1 & 3 & 3 \\
\hline $\begin{array}{l}\text { Reading With } \\
\text { Local Dialect }\end{array}$ & 98 & 98 & 2 & 2 & 0 & 0 \\
\hline $\begin{array}{l}\text { Non-conformity } \\
\text { to Orthographic } \\
\text { Rules }\end{array}$ & 84 & 84 & 8 & 8 & 8 & 8 \\
\hline $\begin{array}{l}\text { Translation of the } \\
\text { Syllable }\end{array}$ & 95 & 95 & 5 & 5 & 0 & 0 \\
\hline $\begin{array}{l}\text { Separating the } \\
\text { Syllable Wrongly }\end{array}$ & 89 & 89 & 2 & 2 & 9 & 9 \\
\hline $\begin{array}{l}\text { Translation of the } \\
\text { Word }\end{array}$ & 100 & 100 & 0 & 0 & 0 & 0 \\
\hline Extending & 99 & 99 & 1 & 1 & 0 & 0 \\
\hline $\begin{array}{l}\text { Not Being Able to } \\
\text { Make Sound }\end{array}$ & 99 & 99 & 1 & 1 & 0 & 0 \\
\hline $\begin{array}{l}\text { Reading by } \\
\text { Bending }\end{array}$ & 74 & 74 & 2 & 2 & 24 & 24 \\
\hline $\begin{array}{l}\text { Following with } \\
\text { Hand or Pencil }\end{array}$ & 74 & 74 & 3 & 3 & 23 & 23 \\
\hline
\end{tabular}

Oral reading mistakes of the students were given as frequency and percentage in Table 2. Oral reading of the students was considered to be free reading level, acceptable level and concern level as can be seen in Table 1. The mistake of translation was recorded to be the word having the highest frequency in the free reading level. In this study, translation mistakes of the students were not identified. Having the highest frequency both at acceptable level and concern level is the mistake of contemplating. It is the reading of the word by students by contemplating the word according to the first syllable. The students made the mistake of contemplating while reading the long words having larger syllables which do not take part in the schema of the students. "Bakrac" (bucket), "batara" (water bottle), "oluğa" (towards the groove) and the word "Turkcelesmistir" (it has been made Turkish) are the words that the students made the mistake of contemplating on most. $38 \%(n=38)$ of the students made oral reading at free level whereas 38\% $(n=$ 38) of them made oral reading at concern level. Another mistake having a high frequency of concern is the mistake of omitting the syllable, where $24 \%(n=24)$ of the students who took part in the sample made this mistake. The students made the mistake of omitting the syllable most in "mataraları" (water bottles) by omitting "ra" syllable and in "ileride" (in the future) by omitting "de" syllable. Once again, $24 \%(n=24)$ of the students made the mistake of reading the text by bending, $23 \%(n=23)$ of them made the mistake of following the text with hand or pencil. The students make the mistakes of reading the text by bending, with hand or by following with pencil. The mistakes of mixing the sounds, reading with local dialect and translation of syllable, translation and extension of words and not being able to make sound have not been identified at the level of concern.

Findings Related to the Sub Problem $2 a$

Table 2. Differentiation t-test in the Mistakes of Oral Reading Depending on Age

\begin{tabular}{|c|c|c|c|c|c|c|c|}
\hline $\begin{array}{l}\text { Oral } \\
\text { Reading } \\
\text { Mistakes }\end{array}$ & $n$ & & Mean & $S D$ & $d f$ & $t$ & $p$ \\
\hline \multirow{2}{*}{$\begin{array}{l}\text { Omitting } \\
\text { the } \\
\text { Syllable }\end{array}$} & $\begin{array}{c}\text { 60-66 } \\
\text { Months }\end{array}$ & 51 & 2.02 & .904 & \multirow[t]{2}{*}{86.783} & \multirow[t]{2}{*}{5.626} & \multirow[t]{2}{*}{.018} \\
\hline & Normally & 49 & 1.23 & .476 & & & \\
\hline \multirow{2}{*}{$\begin{array}{l}\text { Adding the } \\
\text { Syllable }\end{array}$} & $\begin{array}{l}\text { 60-66 } \\
\text { Months }\end{array}$ & 51 & 1.43 & .735 & \multirow[t]{2}{*}{75.276} & \multirow[t]{2}{*}{3.139} & \multirow[t]{2}{*}{.024} \\
\hline & Normally & 49 & 1.09 & .291 & & & \\
\hline
\end{tabular}

A difference was identified between the mistake of syllable omitting and syllable adding when it comes to the relationship between the students starting primary school between the age range of 60-66 months and the students who started the school at their normal age according to Table 2 ( $p<$ .05). The students who started primary school between the age range of 60 and 66 months make the mistake of syllable omitting and syllable adding rather than the students who started the primary school at their normal age.

\section{Findings Related to the Sub Problem $2 b$}

According to the $t$-test which was conducted to measure the oral reading mistakes depending on genders, no difference was found between the genders regarding oral reading mistakes of the students.

\section{Findings Related to the Sub Problem $2 \mathrm{C}$}

The mistake differences were examined whether students started the first reading and writing processes with closed or open syllabus in Table 3. A substantial difference was found in the mistakes of repeating, interruption, omitting the syllable, adding the syllable, not being able to control 
breathing, non-conformity to nonorthographic rules, separating the syllable wrongly, reading by bending, and following with hand or pencil $(p<.05)$. The students who started the primary school writing process with a closed syllable made more oral reading mistakes than the students who started the primary school writing process with an open syllable.

Table 3. Differentiation t-test in Oral Reading Mistakes Depending on the Starting of Writing with Open/Closed Syllable in Primary School

\begin{tabular}{|c|c|c|c|c|c|c|c|}
\hline $\begin{array}{l}\text { Oral Reading } \\
\text { Mistakes }\end{array}$ & $n$ & & Mean & $S D$ & $d f$ & $t$ & $p$ \\
\hline \multirow{2}{*}{ Repeating } & Close & 75 & 1.77 & .831 & \multirow{2}{*}{97.988} & \multirow{2}{*}{4.083} & \multirow{2}{*}{.000} \\
\hline & Open & 25 & 1.08 & .277 & & & \\
\hline \multirow{2}{*}{ Contemplating } & Close & 75 & 2.28 & .817 & \multirow{2}{*}{88.287} & \multirow{2}{*}{9.317} & \multirow{2}{*}{.000} \\
\hline & Open & 56 & 1.16 & .374 & & & \\
\hline \multirow{2}{*}{ Interruption } & Close & 75 & 1.36 & .607 & \multirow{2}{*}{98.000} & \multirow{2}{*}{3.964} & \multirow{2}{*}{.000} \\
\hline & Open & 25 & 1.04 & .321 & & & \\
\hline \multirow{2}{*}{$\begin{array}{l}\text { Omitting the } \\
\text { Syllable }\end{array}$} & Close & 75 & 1.81 & .881 & \multirow{2}{*}{70.430} & \multirow{2}{*}{3.961} & \multirow{2}{*}{.000} \\
\hline & Open & 25 & 1.24 & .521 & & & \\
\hline \multirow{2}{*}{$\begin{array}{l}\text { Adding the } \\
\text { Syllable }\end{array}$} & Close & 75 & 1.37 & .673 & \multirow{2}{*}{74.000} & \multirow{2}{*}{4.802} & \multirow{2}{*}{.000} \\
\hline & Open & 25 & 1.00 & .000 & & & \\
\hline \multirow{2}{*}{$\begin{array}{l}\text { Not Being Able } \\
\text { to Control } \\
\text { Breathing }\end{array}$} & Close & 75 & 1.21 & .576 & \multirow{2}{*}{74.000} & \multirow{2}{*}{3.255} & \multirow{2}{*}{.002} \\
\hline & Open & 25 & 1.00 & .000 & & & \\
\hline \multirow{2}{*}{$\begin{array}{l}\text { Non- } \\
\text { conformity to } \\
\text { Orthographic }\end{array}$} & Close & 75 & 1.32 & .661 & \multirow{2}{*}{74.000} & \multirow{2}{*}{4.193} & \multirow{2}{*}{.000} \\
\hline & Open & 25 & 1.00 & .000 & & & \\
\hline \multirow{2}{*}{$\begin{array}{l}\text { Separating } \\
\text { the Syllable } \\
\text { Wrongly }\end{array}$} & Close & 75 & 1.27 & 664 & \multirow{2}{*}{74.000} & \multirow{2}{*}{3.476} & \multirow{2}{*}{.001} \\
\hline & Open & 25 & 1.00 & 000 & & & \\
\hline \multirow{2}{*}{$\begin{array}{l}\text { Reading by } \\
\text { Bending }\end{array}$} & Close & 75 & 1.64 & 925 & \multirow{2}{*}{91.500} & \multirow{2}{*}{4.197} & 004 \\
\hline & Open & 25 & 1.08 & 400 & & & \\
\hline Following with & Close & 75 & 1.65 & 925 & 70000 & 2520 & P01 \\
\hline Hand or Pencil & Open & 25 & 1.00 & 400 & 17.000 & 3.023 & (1) \\
\hline
\end{tabular}

Table 4. Multivariate Regression Analysis Results Starting of Writing with Open/Closed Syllable in Primary School

\begin{tabular}{lccccc}
\hline Oral Reading Mistakes & $B$ & $S H_{B}$ & $B$ & $t$ & $p$ \\
\hline Constant & 2.637 & .318 & & 8.295 & .000 \\
\hline Repeating & -.071 & .051 & -.129 & -1.388 & .169 \\
\hline Contemplating & -.234 & .049 & -.471 & -4.806 & .000 \\
\hline Adding the Syllable & .037 & .107 & -.051 & -.076 & .566 \\
\hline Adding Sound & .133 & .063 & .117 & 1.245 & .094 \\
\hline $\begin{array}{l}\text { Separating the Syllable } \\
\text { Wrongly }\end{array}$ & .107 & .044 & -.143 & -1.689 & .095 \\
\hline Reading by Bending & .075 & .046 & .147 & -1.431 & .156 \\
\hline Following with Hand or Pencil & .065 & .076 & .127 & -.304 & .762 \\
\hline Interruption & .023 & .073 & -029 & -1.299 & .197 \\
\hline $\begin{array}{l}\text { Not Being Able to Control } \\
\text { Breathing }\end{array}$ & .094 & .102 & -110 & -2.507 & .564 \\
\hline Skipping & -.256 & .266 & -.209 & -.579 & .014 \\
\hline$n=100, R=.687, R^{2}=.472, F=7,153 p<.01$ & & & &
\end{tabular}

Multiple regression analysis, which is related to the association of starting the first writing and reading process with open or closed syllabus with oral reading mistakes, take part in Table 4. Acquisition of the ability of reading the open or closed syllabus have a great importance on mistake types such as contemplating and skipping. $\left(R=687, R^{2}=.472, p<\right.$ $.01)$. Starting with the first writing and reading process with open or closed syllabus accounted for $47 \%$ of oral reading mistakes. When $t$-test results, which are related to the rel- evance of the regression coefficients were evaluated, it was observed that conducting open or closed syllable has a predicting role in the mistakes of contemplating and omitting the syllable.

\section{Findings Related to the Sub Problem $2 d$}

Table 5. Differentiation t-test Depending on the Students Receiving Support at Home or Not in Oral Reading Mistakes

\begin{tabular}{|c|c|c|c|c|c|c|c|}
\hline $\begin{array}{l}\text { Oral Reading } \\
\text { Mistakes }\end{array}$ & \multicolumn{2}{|c|}{$n$} & Mean & $S D$ & $d f$ & $t$ & $p$ \\
\hline \multirow{2}{*}{ Repeating } & Yes & 26 & 1.08 & .272 & \multirow{2}{*}{97.746} & \multirow{2}{*}{-4.241} & \multirow{2}{*}{.000} \\
\hline & No & 74 & 1.78 & .832 & & & \\
\hline \multirow{2}{*}{ Contemplating } & Yes & 26 & 1.23 & .430 & \multirow{2}{*}{84.249} & \multirow{2}{*}{-6.401} & \multirow{2}{*}{.000} \\
\hline & No & 74 & 2.27 & .833 & & & \\
\hline \multirow{2}{*}{ Interrupting } & Yes & 26 & 1.04 & .196 & \multirow{2}{*}{97.606} & \multirow{2}{*}{-2.673} & \multirow{2}{*}{.000} \\
\hline & No & 74 & 1.36 & .610 & & & \\
\hline \multirow{2}{*}{$\begin{array}{l}\text { Omitting the } \\
\text { Syllable }\end{array}$} & Yes & 26 & 1.23 & .514 & \multirow{2}{*}{75.624} & \multirow{2}{*}{-3.239} & \multirow{2}{*}{.002} \\
\hline & No & 74 & 1.86 & .881 & & & \\
\hline \multirow{2}{*}{$\begin{array}{l}\text { Adding the } \\
\text { Syllable }\end{array}$} & Yes & 26 & 1,00 & .000 & \multirow{2}{*}{73.000} & \multirow{2}{*}{-2.843} & \multirow{2}{*}{.005} \\
\hline & No & 74 & 1.38 & .676 & & & \\
\hline \multirow{2}{*}{$\begin{array}{l}\text { Not Being Able } \\
\text { to Control } \\
\text { Breathing }\end{array}$} & Yes & 26 & 1.00 & .000 & \multirow{2}{*}{73.000} & \multirow{2}{*}{-1.895} & \multirow{2}{*}{.002} \\
\hline & No & 74 & 1.22 & .580 & & & \\
\hline \multirow{2}{*}{$\begin{array}{l}\text { Non- } \\
\text { conformity to } \\
\text { Orthographic }\end{array}$} & Yes & 26 & 1.00 & .000 & \multirow{2}{*}{73.000} & \multirow{2}{*}{-2.481} & \multirow{2}{*}{.001} \\
\hline & No & 74 & 1.32 & .664 & & & \\
\hline \multirow{2}{*}{$\begin{array}{l}\text { Separating } \\
\text { the Syllable } \\
\text { Wrongly }\end{array}$} & Yes & 26 & 1.00 & .000 & \multirow{2}{*}{73.000} & \multirow{2}{*}{-2.056} & \multirow{2}{*}{.001} \\
\hline & No & 74 & 1.27 & .668 & & & \\
\hline \multirow{2}{*}{$\begin{array}{l}\text { Reading by } \\
\text { Bending }\end{array}$} & Yes & 26 & 1.08 & .392 & \multirow{2}{*}{94.653} & & \\
\hline & No & 74 & 1.65 & .928 & & 3.090 & .004 \\
\hline Following with & Yes & 26 & 1.00 & .000 & & & \\
\hline Hand or Pencil & No & 74 & 1.66 & .926 & 13.000 & 3.035 & .000 \\
\hline
\end{tabular}

The oral reading mistakes of the students who received supported educationat home as well as those who did not have been evaluated. The students not receiving support on reading at home, made the mistakes of repeating, contemplating, interrupting, omitting the syllable, adding the syllable, not being able to control breathing, non-conformity to nonorthographic rules, separating the syllable wrongly, reading by bending, and following with hand or pencil are more than the students who received support at home $(p<.05)$.

Table 6. Multivariate Regression Analysis Results Among the Students Who Received Support Education at Home and Invariables

\begin{tabular}{lccccc}
\hline Oral Reading Mistakes & $B$ & $S H_{B}$ & $B$ & $t$ & $p$ \\
\hline Constant & -.286 & .700 & & -.409 & .684 \\
\hline Repeating & -.088 & .056 & .157 & 1.572 & .120 \\
\hline Contemplating & .043 & .059 & .392 & 3.367 & .001 \\
\hline Adding the Syllable & .038 & .074 & .052 & .515 & .608 \\
\hline Omitting the Syllable & .032 & .057 & .061 & .559 & .578 \\
\hline $\begin{array}{l}\text { Separating the Syllable } \\
\text { Wrongly }\end{array}$ & .092 & .073 & .123 & 1.256 & .213 \\
\hline $\begin{array}{l}\text { Skipping } \\
\text { Interrupting }\end{array}$ & .264 & .110 & .213 & 2.399 & .019 \\
\hline $\begin{array}{l}\text { Not Being Able to Control } \\
\text { Breathing }\end{array}$ & .073 & .084 & .085 & .877 & .383 \\
\hline $\begin{array}{l}\text { Following with Hand or } \\
\text { Pencil }\end{array}$ & -.256 & .266 & -.209 & -.579 & .564 \\
\hline
\end{tabular}

$n=100, R=.684, R^{2}=.468, F=4,249 p<.01$ 
There is a multiple regression analysis in Table 6 related to the association of receiving/or not receiving the support education at home with oral reading mistakes. There is a strong relationship between time dependent oral reading mistakes and oral reading mistakes. $\left(R=684, R^{2}=.468, p<\right.$ .01). Time dependent oral reading explains for $47 \%$ of the oral reading mistakes. When $t$-test results, which are related to the relevance of the regression coefficients, were evaluated, it has been observed to be a predictor in the mistakes of receiving support at home/or not, contemplating and skipping.

\section{Findings Related to the Sub Problem $2 e$}

Table 7. Differentiation t-test in the Mistakes of Oral Reading Depending on the Teachers Receiving Consultancy/ or not

\begin{tabular}{|c|c|c|c|c|c|c|c|}
\hline $\begin{array}{l}\text { Oral Reading } \\
\text { Mistakes }\end{array}$ & $\mathrm{n}$ & & Mean & $S D$ & $d f$ & $t$ & $p$ \\
\hline \multirow{2}{*}{ Repeating } & Yes & 25 & 1.08 & .277 & \multirow{2}{*}{97.988} & \multirow{2}{*}{-4.083} & \multirow{2}{*}{.000} \\
\hline & No & 75 & 1.77 & .831 & & & \\
\hline \multirow{2}{*}{ Contemplating } & Yes & 25 & 1.20 & .408 & \multirow{2}{*}{83.781} & \multirow{2}{*}{-6183} & \multirow{2}{*}{.000} \\
\hline & No & 75 & 2.27 & .827 & & & \\
\hline \multirow{2}{*}{ Interruption } & Yes & 25 & 1.04 & 200 & \multirow{2}{*}{98.000} & \multirow{2}{*}{-2.581} & \multirow{2}{*}{.000} \\
\hline & No & 75 & 1.36 & .607 & & & \\
\hline \multirow{2}{*}{$\begin{array}{l}\text { Omitting the } \\
\text { Syllable }\end{array}$} & Yes & 25 & 1.20 & .500 & \multirow{2}{*}{73.312} & \multirow{2}{*}{-3.391} & \multirow{2}{*}{.000} \\
\hline & No & 75 & 1.83 & .876 & & & \\
\hline \multirow{2}{*}{$\begin{array}{l}\text { Adding the } \\
\text { Syllable }\end{array}$} & Yes & 25 & 1,00 & .000 & \multirow{2}{*}{74.000} & \multirow{2}{*}{-2.763} & \multirow{2}{*}{.001} \\
\hline & No & 75 & 1.38 & .576 & & & \\
\hline \multirow{2}{*}{$\begin{array}{l}\text { Not Being Able } \\
\text { to Control } \\
\text { Breath }\end{array}$} & Yes & 25 & 1.00 & .000 & \multirow{2}{*}{74.000} & \multirow{2}{*}{-1.844} & \multirow{2}{*}{.002} \\
\hline & No & 75 & 1.21 & .673 & & & \\
\hline \multirow{2}{*}{$\begin{array}{l}\text { Non- } \\
\text { conformity to } \\
\text { Orthographic }\end{array}$} & Yes & 25 & 1.00 & .000 & \multirow{2}{*}{74.000} & \multirow[b]{2}{*}{-2.413} & \multirow[b]{2}{*}{.001} \\
\hline & No & 75 & 1.32 & .661 & & & \\
\hline \multirow{2}{*}{$\begin{array}{l}\text { Separating } \\
\text { the Syllable } \\
\text { Wrongly }\end{array}$} & Yes & 25 & 1.00 & .000 & \multirow{2}{*}{74.000} & \multirow{2}{*}{-2.000} & \multirow{2}{*}{.001} \\
\hline & No & 75 & 1.27 & .664 & & & \\
\hline \multirow{2}{*}{$\begin{array}{l}\text { Reading by } \\
\text { Bending }\end{array}$} & Yes & 25 & 1.08 & .000 & \multirow{2}{*}{74.000} & \multirow{2}{*}{3.554} & 001 \\
\hline & No & 75 & 1.67 & .935 & & & (.001 \\
\hline Following with & Yes & 25 & 1.00 & .000 & & 3570 & ( \\
\hline & No & 75 & 1.65 & .923 & 14.000 & 3.529 & (.001 \\
\hline
\end{tabular}

The difference whether to receive consultancy support from an expert or not has been examined in the stage of primary school for classroom teachers. The students who started the writing process with the closed syllable made the mistakes of repeating, contemplating, interrupting, omitting the syllable, adding the syllable, not being able to control breathing, non-conformity to nonorthographic rules, separating the syllable wrongly, reading by bending and following with hand or pencil are more than that of the students who started the writing process with an open syllable $(p<.05)$.

Table 8. Multivariate Regression Analysis Results of the Classroom Student Among the Receiving Expert Consultancy and Oral Reading Mistakes

\begin{tabular}{lccccc}
\hline Oral Reading Mistakes & $B$ & $S H_{B}$ & $B$ & $t$ & $p$ \\
\hline Constant & -239 & .680 & & .351 & .726 \\
\hline Contemplating & .203 & .057 & .408 & 3.557 & .001 \\
\hline Skipping & .267 & .107 & .218 & 2.494 & .015 \\
\hline Reading by Bending & .125 & .048 & -.246 & 2.588 & .011 \\
\hline$n=100, R=.686, R^{2}=.484, F=4,529$ & $p<.01$ & & & &
\end{tabular}

There is a multiple regression analysis in Table 8 related to the association of the classroom teachers receiving/or not receiving the expert consultancy with oral reading mistakes.
The classroom teachers receiving an expert consultancy during the first writing process have a substantial influence upon contemplating, skipping and reading by bending. $\left.R=.686, R^{2}=.484, p<.01\right)$. Receiving an expert consultancy/ or not in the first writing and reading period accounts for $48 \%$ the oral reading mistakes. When $t$-test results, which are related to the relevance of the regression coefficients, were evaluated, it was observed that receiving a consultancy service/or not, have a predicting role in the mistakes of contemplating and reading by bending.

\section{Findings Related to the Sub Problem $2 f$}

Table 9. Differentiation t-test on the Oral Reading Mistakes Depending on Emotional Problems

\begin{tabular}{|c|c|c|c|c|c|c|c|}
\hline $\begin{array}{l}\text { Oral Reading } \\
\text { Mistakes }\end{array}$ & \multicolumn{2}{|c|}{$n$} & Mean & $S D$ & $d f$ & $t$ & $p$ \\
\hline \multirow{2}{*}{ Repeating } & Yes & 41 & 1.86 & .843 & 77.691 & 2.200 & .030 \\
\hline & No & 59 & 1.42 & .727 & 83.636 & 3.420 & .001 \\
\hline \multirow{2}{*}{ Contemplating } & Yes & 41 & 2.34 & .855 & 53.186 & 3.291 & .005 \\
\hline & No & 59 & 1.76 & .817 & 68.660 & 4.031 & .000 \\
\hline \multirow{2}{*}{ Interruption } & Yes & 41 & 1.49 & .711 & 65.341 & 2.603 & .011 \\
\hline & No & 59 & 1.14 & .345 & 40.000 & 4.033 & .000 \\
\hline \multirow{2}{*}{$\begin{array}{l}\text { Omitting the } \\
\text { Syllable }\end{array}$} & Yes & 41 & 2.05 & .921 & 44.186 & 4.165 & .000 \\
\hline & No & 59 & 1.41 & .673. & 48.601 & 2.798 & .006 \\
\hline \multirow{2}{*}{$\begin{array}{l}\text { Adding the } \\
\text { Syllable }\end{array}$} & Yes & 41 & 1.46 & .711 & 67.228 & 2.817 & .006 \\
\hline & No & 59 & 1.15 & .485 & 65.048 & 3.528 & .001 \\
\hline \multirow{2}{*}{ Adding Sound } & Yes & 41 & 1.29 & .559 & 77.691 & 2.200 & .030 \\
\hline & No & 59 & 1.00 & .000 & 83.636 & 3.420 & .001 \\
\hline \multirow{2}{*}{$\begin{array}{l}\text { Non- } \\
\text { conformity to } \\
\text { Orthographic }\end{array}$} & Yes & 41 & 1.51 & .810 & 53.186 & 3.291 & .005 \\
\hline & No & 59 & 1.05 & .222 & 68.660 & 4.031 & .000 \\
\hline \multirow{2}{*}{$\begin{array}{l}\text { Separating } \\
\text { the Syllable } \\
\text { Wrongly }\end{array}$} & Yes & 41 & 1.39 & .802 & 65.341 & 2.603 & .011 \\
\hline & No & 59 & 1.07 & .314 & 40.000 & 4.033 & .000 \\
\hline \multirow{2}{*}{$\begin{array}{l}\text { Reading by } \\
\text { Bending }\end{array}$} & Yes & 41 & 1.78 & .988 & 44.186 & 4.165 & .000 \\
\hline & No & 59 & 1.31 & .401 & 48.601 & 2.798 & .006 \\
\hline \multirow{2}{*}{$\begin{array}{l}\text { Following with } \\
\text { Hand or Pencil }\end{array}$} & Yes & 41 & 1.83. & .972 & 67.228 & 2.817 & .006 \\
\hline & No & 59 & 1.25 & .659 & 65.048 & 3.528 & .001 \\
\hline
\end{tabular}

Emotional problems are the problems such as division of family, death of mother, father or both of them, being subjected to violence, or experiencing an accident. The students who have one or more of these problems make the mistakes of repeating, contemplating, interrupting, omitting the syllable, adding the syllable, not being able to control breathing, non-conformity to nonorthographic rules, separating the syllable wrongly, reading by bending, following with hand or pencil more than the students who did not have these emotional problems $(p<.05)$.

Table 10. Multivariate Regression Analysis Results Among Having an Emotional Problem and Variables

\begin{tabular}{lccccc}
\hline Oral Reading Mistakes & $B$ & $S_{B}$ & $B$ & $t$ & $p$ \\
\hline Constant & 4.238 & .756 & & 5,603 & .000 \\
\hline Omitting the Syllable & -.130 & .062 & -.221 & -2.908 & .039 \\
\hline Mixing the Sounds & -.527 & .129 & -.139 & -2.008 & .048 \\
\hline Skipping & -.308 & .119 & -.221 & -2.587 & .011 \\
\hline Reading by Bending & -.163 & .054 & -.283 & -3.044 & .003 \\
\hline Following with Hand or Pencil & -.161 & 053 & -.276 & -3.015 & .003 \\
\hline
\end{tabular}

In table 10, Multiple regression analysis exists, which is related to the association of the emotional problems such as family division that the student experienced or is currently experiencing in Table 10, death of mother, father or both of 
them, encountering an accident, being subjected to violence, with the oral reading mistakes. Having an emotional issue has an immense effect upon the mistakes such as omitting the syllable, mixing and skipping the sounds, and following with hand and pencil. $\left(R=.711, R^{2}=.506, p<.01\right)$. Emotional problems accounts for $51 \%$ of oral reading mistakes. When $t$-test results, which are related to the relevance of the regression coefficients, were evaluated, it was observed that these results have a meaningful predictor on omitting the syllable, mixing and skipping the sounds, reading by bending, and following by hand or pencil.

\section{Findings Related to the Sub Problem $2 g$}

Table 11. Differentiation t-test in the Mistakes of Time Dependent Oral Readings

\begin{tabular}{|c|c|c|c|c|c|c|c|}
\hline $\begin{array}{l}\text { Oral Reading } \\
\text { Mistakes }\end{array}$ & & & Mean & ss & $S D$ & $t$ & $p$ \\
\hline \multirow{2}{*}{ Repeating } & Yes & 56 & 1.88 & .875 & \multirow{2}{*}{89.293} & \multirow[b]{2}{*}{4.523} & \multirow{2}{*}{.000} \\
\hline & No & 44 & 1.25 & .488 & & & \\
\hline \multirow{2}{*}{ Contemplating } & Yes & 56 & 2.38 & .822 & \multirow{2}{*}{97.356} & \multirow{2}{*}{5.603} & \multirow{2}{*}{.000} \\
\hline & No & 44 & 1.52 & .698 & & & \\
\hline \multirow{2}{*}{ Interruption } & Yes & 56 & 1,41 & .654 & \multirow{2}{*}{83.798} & \multirow{2}{*}{2.972} & \multirow{2}{*}{.007} \\
\hline & No & 44 & 1,11 & .321 & & & \\
\hline \multirow{2}{*}{$\begin{array}{l}\text { Omitting the } \\
\text { Syllable }\end{array}$} & Yes & 56 & 2.02 & .904 & \multirow{2}{*}{86.783} & \multirow{2}{*}{5.626} & \multirow{2}{*}{.00} \\
\hline & No & 44 & 1.23 & .476 & & & \\
\hline \multirow{2}{*}{$\begin{array}{l}\text { Adding the } \\
\text { Syllable }\end{array}$} & Yes & 56 & 1.43 & .735 & \multirow{2}{*}{75.276} & \multirow{2}{*}{3.139} & \multirow{2}{*}{.00} \\
\hline & No & 44 & 1.09 & .291 & & & \\
\hline \multirow{2}{*}{$\begin{array}{l}\text { Not Being Able } \\
\text { to Control } \\
\text { Breath }\end{array}$} & Yes & 56 & 1.27 & .646 & \multirow{2}{*}{62.495} & \multirow{2}{*}{2.744} & \multirow{2}{*}{.008} \\
\hline & No & 44 & 1.02 & .151 & & & \\
\hline \multirow{2}{*}{$\begin{array}{l}\text { Non- } \\
\text { conformity to } \\
\text { Orthographic }\end{array}$} & Yes & 56 & 1.39 & .731 & \multirow{2}{*}{66.311} & \multirow[b]{2}{*}{3.384} & \multirow{2}{*}{.003} \\
\hline & No & 44 & 1.05 & .211 & & & \\
\hline \multirow{2}{*}{$\begin{array}{l}\text { Separating } \\
\text { the Syllable } \\
\text { Wrongly }\end{array}$} & Yes & 56 & 1.89 & .985 & \multirow{2}{*}{55.000} & \multirow[b]{2}{*}{6.784} & \multirow{2}{*}{.000} \\
\hline & No & 44 & 1.00 & .000 & & & \\
\hline \multirow{2}{*}{$\begin{array}{l}\text { Reading by } \\
\text { Bending }\end{array}$} & Yes & 56 & 1.86 & .980 & \multirow{2}{*}{58.213} & \multirow{2}{*}{6.276} & (200 \\
\hline & No & 44 & 1.02 & .151 & & & .000 \\
\hline Following with & Yes & 56 & 1.86 & .980 & & & (2) \\
\hline Hand or Pencil & No & 44 & 1.02 & .151 & S0.213 & 0.210 & .000 \\
\hline
\end{tabular}

In the table, a couple of words were read in a couple of minutes, and the impact of time dependent reading on the reading mistakes have been revealed. The students who made time dependent by their teachers or families, mistakes of repeating, contemplating, interrupting, omitting the syllable, adding the syllable, not being able to control breathing, non-conformity to nonorthographic rules, separating the syllable wrongly, reading by bending, and following with hand or pencil are more than the students who did not.

Table 12. Multivariate Regression Analysis Results Among Time Dependent Reading and Oral Reading Mistakes

\begin{tabular}{lccccc}
\hline $\begin{array}{l}\text { Oral Reading } \\
\text { Mistakes }\end{array}$ & $B$ & $S H_{B}$ & $B$ & $t$ & $P$ \\
\hline Constant & 2.562 & .0998 & & 26.047 & .000 \\
\hline Omitting the Syllable & -.249 & .038 & -.419 & -6.416 & .000 \\
\hline Reading by Bending & -.244 & .038 & -.420 & -6.416 & .000 \\
\hline $\begin{array}{l}\text { Following with Hand } \\
\text { or Pencil }\end{array}$ & .229 & -.039 & -.388 & -5.936 & .000 \\
\hline$n=100, R=.778, R^{2}=.605, F=49,009$ & $p<.01$ & & &
\end{tabular}

Multiple regression analysis which is related to the association of time dependent reading with the oral reading mistakes in Table 12. Reading based upon the time dependent method, has an important impact on the mistakes such as omitting the syllable, reading by bending, and following by hand and pencil. $\left(R=.778, R^{2}=.605, p<.01\right)$. Time dependent oral reading accounts for $61 \%$ of oral reading mistakes. When t-test results, which are related to the relevance of the regression coefficients were examined, it was observed that time dependent reading is a predictor on the mistakes such as omitting the syllable, reading by bending, and following by hand or pencil.

\section{Findings Related to the Sub Problem $2 h$}

An anova test was performed in order to examine the impact of the students' completion time of reading and writing upon the oral reading mistakes in Table 13. The oral reading mistakes of the students vary on the level of $p<.05$ depending on the completion time of the first reading and writing of students. A substantial difference has been found in the mistakes of contemplating, interrupting, omitting the syllable, adding the syllable, separating the syllable wrongly and bending depending on the time of reading the text. The Ministry of National Education states that the first reading and writing process in the 2005 program as the second term of December and the last week of March. In the Tukey test, which was implemented in order to identify the source of difference, the students who completed the first reading and writing period after the normal time made the mistakes of contemplating, interrupting and omitting the syllable more than that of the students who completed it on the normal time and before the normal time. The students who completed the first reading and writing process before the normal time, made the mistake of adding the syllable more than the students who completed it in the normal time. The students who completed the first reading and writing process before and after the normal time, made the mistake of separating the syllable wrongly more frequently than the students who completed it in the normal time. The students who completed the first reading and writing process after the normal time, make the mistake of reading by bending more regularly than the students who completed the first reading and writing process in its normal time

\section{Findings Related to the Sub Problem $2 i$}

A substantial difference was found in the Anova test in order to reveal the difference between students' period of reading the text and oral reading mistakes $(p<.05)$. The Tukey test was carried out in order to identify the source of the difference. As the reading time of the student increases, so does the frequency of repeating mistake. Once again, as the students' time of reading increases, do does the frequency of making the interrupting mistake. However, no difference was found between the times of reading the text in and under two minutes and other oral reading times. Fast reading does not have any contribution to decreasing the recurrance of mistakes. As the reading times of the students increases, the mistake of omitting the syllable also rises. Once again, speedy reading does not decrease the probability of omitting the syllable mistake. As the students' reading time of the text increases, so does the mistake level of adding sound. The students whose reading times were between 3.01 and 4 minutes made the mistake of non-conformity to nonorthographic rules more than the students whose reading times were between 2.31 and 3 minutes. The students whose reading times were between 3.01 and 4 minutes made the mistake of separating the syllable wrongly more than the students whose reading times were between 2.31 and 3 minutes.

There is a multiple regression analysis in Table 15, which is related to the identification of oral reading mistakes. Occupation of father, educational background of father, occupation of mother, educational background of mother, status of income, period of completing the first reading and writing process, socio-economic status of the school do not have an 
Table 13. Differentiation in Oral Reading Mistakes Depending on the Completion Times of Reading and Writing

\begin{tabular}{|c|c|c|c|c|c|c|c|}
\hline Oral Reading Mistakes & Resource of Difference & $\begin{array}{l}\text { Sum of } \\
\text { Squares }\end{array}$ & $d f$ & $\begin{array}{l}\text { Mean } \\
\text { Square }\end{array}$ & $F$ & $p$ & Mean Difference I-J \\
\hline \multirow{3}{*}{ Contemplating } & Between Groups & 3.512 & 2 & \multirow{3}{*}{$\begin{array}{c}5.790 \\
.537\end{array}$} & \multirow{3}{*}{8.718} & \multirow{3}{*}{.000} & \multirow{3}{*}{$\begin{array}{l}\text { ANT>ONT } \\
\text { ANT }>\text { BNT }\end{array}$} \\
\hline & Within Groups & 51.041 & 97 & & & & \\
\hline & Total & 62.000 & 99 & & & & \\
\hline \multirow{3}{*}{ Interrupting } & Between Groups & 5.237 & 2 & \multirow{3}{*}{$\begin{array}{c}2.618 \\
.257\end{array}$} & \multirow{3}{*}{10.191} & \multirow{3}{*}{.000} & \multirow{3}{*}{$\begin{array}{l}\text { ANT>ONT } \\
\text { ANT }>\text { BNT }\end{array}$} \\
\hline & Within Groups & 22.460 & 97 & & & & \\
\hline & Total & 30.160 & 99 & & & & \\
\hline \multirow{3}{*}{ Omitting the Syllable } & Between Groups & 9.918 & 2 & \multirow{3}{*}{$\begin{array}{c}2.479 \\
.634\end{array}$} & \multirow{3}{*}{4.440} & \multirow{3}{*}{.000} & \multirow{3}{*}{$\begin{array}{l}\text { ANT>ONT } \\
\text { ANT }>\text { BNT }\end{array}$} \\
\hline & Within Groups & 60.192 & 97 & & & & \\
\hline & Total & 70.110 & 99 & & & & \\
\hline \multirow{3}{*}{ Adding the Syllable } & Between Groups & 2.968 & 2 & \multirow{3}{*}{$\begin{array}{c}2.469 \\
.383\end{array}$} & \multirow{3}{*}{6.446} & \multirow{3}{*}{.017} & \multirow{3}{*}{ BNT>NS } \\
\hline & Within Groups & 33.192 & 97 & & & & \\
\hline & Total & 36.160 & 99 & & & & \\
\hline \multirow{3}{*}{ Separating the Syllable } & Between Groups & 2.550 & 2 & \multirow{3}{*}{$\begin{array}{c}1.275 \\
.324\end{array}$} & \multirow{3}{*}{3.932} & \multirow{3}{*}{.002} & \multirow{3}{*}{$\begin{array}{l}\text { BNT>ONT } \\
\text { ANT }>\text { ONT }\end{array}$} \\
\hline & Within Groups & 31.450 & 97 & & & & \\
\hline & Total & 34.000 & 99 & & & & \\
\hline \multirow{3}{*}{ Reading by Bending } & Between Groups & 5.248 & 2 & \multirow{3}{*}{$\begin{array}{c}2.624 \\
.698\end{array}$} & \multirow{3}{*}{3.756} & \multirow{3}{*}{.002} & \multirow{3}{*}{ ANT $>$ ONT } \\
\hline & Within Groups & 67.752 & 97 & & & & \\
\hline & Total & 73.000 & 99 & & & & \\
\hline
\end{tabular}

BNT= Before normal time, ONT= On normal time, ANT=After normal time:

Table 14. Differentiation in Oral Reading Mistakes Depending on the Completion Times of Reading and Writing

\begin{tabular}{|c|c|c|c|c|c|c|c|}
\hline Oral Reading Mistakes & Resource of Difference & $\begin{array}{l}\text { Sum of } \\
\text { Squares }\end{array}$ & $d f$ & $\begin{array}{l}\text { Mean } \\
\text { Square }\end{array}$ & $F$ & $p$ & Mean Difference I-J \\
\hline \multirow{3}{*}{ Repeating } & Between Groups & 10.498 & 4 & \multirow{3}{*}{$\begin{array}{c}2.740 \\
.537\end{array}$} & \multirow{3}{*}{5.099} & \multirow{3}{*}{.001} & \multirow{3}{*}{$\begin{array}{c}4.01 \text { and } a b o .>2.01-2.30 \\
4.01 \text { and abo. }>2.31-3.00 \\
3.01-4.00>2.01-2.30\end{array}$} \\
\hline & Within Groups & 51.041 & 95 & & & & \\
\hline & Total & 62.000 & 99 & & & & \\
\hline \multirow{3}{*}{ Interrupting } & Between Groups & 7.760 & 4 & \multirow{3}{*}{$\begin{array}{l}1.940 \\
.236\end{array}$} & \multirow{3}{*}{8.228} & \multirow{3}{*}{.000} & \multirow{3}{*}{$\begin{array}{c}4.01 \text { and above }>0-2,00 \\
4.01 \text { and abo. }>2.01-2.30 \\
4.01 \text { and above }>2.31-3.00 \\
3.01-4.00>2.01-2.30 \\
3.01-4>2.31-3.00\end{array}$} \\
\hline & Within Groups & 22.460 & 95 & & & & \\
\hline & Total & 30.160 & 99 & & & & \\
\hline \multirow{3}{*}{ Omitting the Syllable } & Between Groups & 9.918 & 4 & \multirow{3}{*}{$\begin{array}{c}2.479 \\
.634\end{array}$} & \multirow{3}{*}{4.440} & \multirow{3}{*}{.006} & \multirow{3}{*}{$\begin{array}{c}4.01 \text { and abo. }>2.01-2.30 \\
3.01-4.00 \mathrm{i}>2.31-3.00\end{array}$} \\
\hline & Within Groups & 60.192 & 95 & & & & \\
\hline & Total & 70.110 & 99 & & & & \\
\hline \multirow{3}{*}{ Adding Sound } & Between Groups & 2.549 & 4 & \multirow{3}{*}{$\begin{array}{c}2.469 \\
.383\end{array}$} & \multirow{3}{*}{6.446} & \multirow{3}{*}{.002} & \multirow{3}{*}{$\begin{array}{c}4.01 \text { and above }>0-2,00 \\
4.01 \text { and above }>2.01-2.30 \\
4.01 \text { and abo. }>2.30-3.00\end{array}$} \\
\hline & Within Groups & 70.260 & 95 & & & & \\
\hline & Total & 72.819 & 99 & & & & \\
\hline \multirow{3}{*}{$\begin{array}{l}\text { Non-conformity to } \\
\text { Orthographic }\end{array}$} & Between Groups & 4.798 & 4 & \multirow{3}{*}{$\begin{array}{c}1.200 \\
.310\end{array}$} & \multirow{3}{*}{3.870} & \multirow{3}{*}{.006} & \multirow{3}{*}{$3.01-4.00>2.31-3.00$} \\
\hline & Within Groups & 29.4422 & 95 & & & & \\
\hline & Total & 34.240 & 99 & & & & \\
\hline \multirow{3}{*}{ Separating the Syllable } & Between Groups & 4,851 & 4 & \multirow{3}{*}{$\begin{array}{l}1.213 \\
.307\end{array}$} & \multirow{3}{*}{4.440} & \multirow{3}{*}{.006} & \multirow{3}{*}{$\begin{array}{c}3.01-4.00>0-2,00 \\
3.01-4.00>2.31-3.00\end{array}$} \\
\hline & Within Groups & 29.149 & 95 & & & & \\
\hline & Total & 34.000 & 99 & & & & \\
\hline
\end{tabular}

0-2: Reading the text in less than two minutes; 2.01-2.30: Reading the text within two minutes or between two minutes and thirty seconds; 2.31-3: Reading the text within 2 minutes or between 31 seconds and 3 minutes; 3.01-4:Reading the text within 3.01 and 4 minutes; 4.01 and above: Reading the text in more than four minutes significant impact upon the mistakes of oral reading. ( $R=$ Findings Related to the Sub Problem $2 k$ $\left.487, R^{2}=237, p<.01\right)$ The relevant variables only account for $24 \%$ of oral reading mistakes.

Table 15. Multivariative Regression Analysis Result Among the Variables

\begin{tabular}{llllll}
\hline Oral Reading Mistakes & $B$ & $S H B$ & $\beta$ & $t$ & $p$ \\
\hline Constant & .891 & .554 & & 1.607 & .111 \\
\hline Period of completing the first & .392 & .167 & .265 & 2.351 & .021 \\
\hline Text Reading Time & .067 & .088 & .084 & .767 & .445 \\
\hline Socio-economic status & .146 & .116 & .148 & 1.255 & .213 \\
\hline$n=100, R=.487, R^{2}=.237, F=3,531$ & $p<.01$ & & & &
\end{tabular}

The mistakes of the students do not vary according to the method of forming the classrooms. Coexistence of the students in mixed classrooms and the students who are at the age of 60-66 months do not affect oral reading mistakes of the students.

\section{Conclusion}

Reading is a different type of development among the other native language abilities as it takes longer for students to acquire both vocal and silent reading abilities. So reading involves a certain process (Al Farsi, 2018; Kearns; Rogers 
\& Koriakin, 2016; Tabačková, 2015). This skill is a complex process (Joyce, Hood \& Rose, 2008; Zera \& Lucian, 2001; Jeffrey, 2000;). Reading is an activity that involves comprehension and interpretation (Shea \& Ceprano, 2017; Akyol, 2011; Yangın, 2002; Öz, 2001; Güneş, 2000; Zhang, 1999; Bamberger, 1990). This study especially focused on oral reading implementations. Classroom teachers conduct various studies in order to increase the level and speed of the students. Oral reading mistakes have been identified in this study, and contemplating and omitting the syllable are the mistakes the students made most during the reading sessions. The students who started the primary school between the age range of 60-66 months have been recorded to have made more mistakes than the students who had completed their 72 month when starting school. This circumstance can be linked with that the students at the age range of 60-66 months cannot discern the abstract rules of the language completely and not being able to form a relationship between oral reading and speaking rules. It has been identified that the students who started the first reading and writing with a closed syllable make more mistakes than the students who started the first reading and writing with an open syllable. Open syllables have been effective in oral reading since it is convenient for the logic of langauge. The study which was conducted by Başar et.al., (2015) supports this finding. In their study, Başar, et. al., concluded that the oral reading decreases among students who conduct the first reading process with an open syllable. The students who did not receive support at home made more mistakes than the ones who received support. The students can develop their ability of reading by practicing at home. The teacher who received the expert support has been recorded to have made less reading mistakes than the students whose teacher did not receive support. The teachers adopt a positive attitude towards the students during the oral reading and this reveals the importance of the experts. The students who had or were experiencing emotional problems made more mistakes than other students. This can be linked to the family problems that the students cannot learn and focus on the words completely. In this regard, recognizing the word affects the reading fluency positively (Yamaç, 2014; Dağ, 2010). Razon (2007) states that emotional problems affect the reading abilities of the students negatively. The students who delivered time dependent reading make more mistakes than those students who delivered without time dependent reading. This case might have taken place due to the students focusing on uttering the words rapidly instead of patiently and correctly, as well as the pressure that the students felt based on the time period that they were exposed to. Başar et.al., (2014) identified that the time dependent reading studies have a negative impact upon reading and comprehension as it increases the reading mistakes. The educational background and socio-economic status of the family has an impact upon oral reading. It is seen that as the educational background of the family recovers, so does the number of oral reading mistakes of the students. This circumstance overlaps the studies of Dökmen (1994) and, Topçuoğlu and Yigit (2014) related to the impact of the family upon reading ability. As long as the time given to reading increases, so does the number of mistakes during the reading activity. (This is because the students distract their attention gradually and they focus on reading fast and vocalizing and their mistakes increase. This also coincides with similar studies (Blackwell, 1962; Dudley \& Mather, 2005; Genovese, Pellegrini, \& Geraci, 2007; Tsvetkova, 2017). The number of mistakes increases as the time given for reading increases, and the number of mistakes increase as the time given for reading decreases. It can be stated that reading a text speedily does not make the relevant student good at reading a text. In conclusion, oral reading mistakes do not change depending on the classroom levels. There is not a linear relationship between the ages and academic successes of students.

\section{References}

Akyol, H. (2012). Programa Uygun Türkçe Öğretim Yöntemleri, Ankara: Pegem Akademi

Akyol, H. (2011). Türkçe Illkokuma Yazma Öğretimi, Ankara: Pegem Akademi.

Anılan, H., Bay, Y. (2015) The view of teachers of first graders regarding scheduling the age of starting school to an earlier time, Mevlana International Journal of Education (MIJE) 5(1) 26-44

Allington, R. L. (2014). How reading volume affects both reading fluency and reading achievement, International Electronic Journal of Elementary Education (IEJEE), 7(1), 13-26.

AlFarsi, B. (2018). Word meaning in word identification during reading: Co-occurrence-based semantic neighborhood density effects, Applied Psycholinguistics, 39(5), 779-809.

Bamberger, R. (1990). Okuma Alışkanlığını Geliştirme, Ankara: Kültür Bakanlığı Yayınları(Çev.B.Çapar).

Başar, M., Doğan, M.C., Şener, N., Karasu, M., Yurttaş, R. (2015). Illkokuma yazma sürecine açık ya da kapalı hece ile başlamak, International Journal of Language Acedemy 3 (4) 442-452

Başar, M, Batur, Z., Karasu, M. (2014). Süreye bağlı okumanın okuduğunu anlama üzerine etkisi, Milli Eğitim Dergisi 203. 5-22

Başar, M. (2013). 60-66 ay yaş aralığında ilkokula başlayan öğrencilerin kişisel özbakım ve ilkokuma-yazma becerilerinin öğretmen görüșlerine göre değerlendirilmesi, International Periodical For The Languages Literature and History of Turkish or Turkic 8 (8) 241-252

Begeny, J.C., Martens, B.K. (2006). Assisting low-performing readers with a group based reading fluency intervention. School Psychology Review, 35, 91-107.

Blackwell,W.(1962). Peripheral vision, refractorıness and eye movements in fast oral reading, British Journal of PSychology, 53(4), 409-419.

Dağ, N. (2010). Okuma güçlüğünün giderilmesinde 3P metodu ile boşluk tamamlama (Cloze) tekniğinin kullanımı üzerine bir çalışma, Ankara Üniversitesi Eğitim Bilimleri Fakültesi Özel Eğitim Dergisi, 11(1), 63-74.

Dökmen, Ü. (1994). Okuma Becerisi, ilgisi ve Alışkanlığı Üzerine Psikososyal Bir Araştırma, İstanbul: Milli Eğitim Yayınları.

Dudley, A. M.; Mather, N. (2005). Getting up to speed on reading fluency, New England Reading Association Journal , 41(1), 22-27.

Duran, E. (2013). 60. ayında ilkokula başlayan öğrencilerin yazı becerilerinin incelenmesi, Journal of Academic Social Science Studies 6(2) 1075-1085

Emiroğlu, S. (2013). Türkçe öğretmeni adaylarının dinleme sorunlarına ilişkin görüşleri, Adıyaman Üniversitesi Sosyal Bilimler Enstitüsü Dergisi Türkçenin Eğitimi Öğretimi Özel Sayısı, 11, 269-307.

Genovese, M. L., Pellegrini, M., Geraci, F. (2007). A fast and accurate heuristic for the single individual snp haplotyping problem with many gaps, high reading error rate and low coverage, Filippo, Erişim Numarası: edsair. od......2367..54fe683d6b552b473b7c17b695d66a76 (27.10.2018). 
Günes, F. (2000). Türkçe Uygulamalı Okuma Yazma Öğretimi, Ankara: Ocak Yayıncilık.

Işık, A., E. (2014). 60-66 Aylıkken Okula Baş/ayan Öğrencilerin Okuma Yazma Becerilerinin Incelenmesi, Yayımlanmamış Yüksek Lisans Tezi) Uşak Üniversitesi, Sosyal Bilimler Enstitüsü.

Jeffrey J. W. (2000). The interplay between automatic and control processes in reading, Reading Research Quarterly, 35(4), 554-566.

Joyce, H., Hood, S. and Rose, D. (2008). Investigating the impact of intensive reading pedagogy in adult literacy, Australia: Published by NCVER

Karasar, N. (2011). Bilimsel Araştırma Yöntemi, Ankara: Nobel Yayın Dağıtım.

Kearns, D. M.; Rogers, H. J. and Koriakin, T.(2016). Semantic and phonological ability to adjust recoding: a unique correlate of word reading skill? Scientific Studies of Reading 20(16) 455-470

Kırmızı Susar, F. (2015). 12 Haftalık Uyum ve Hazırlık Süreci Uygulamalarına İlişkin 1. Sınıf Öğretmenlerinin Görüşleri, Eğitim ve Bilim, 179, 147-162

Lui, Z. (2009). A study on CPH and debate summary in FLL, English Language Teaching, 2(3), 120-128

Kathleen F. and Mcneal, K. (2017). Creating cartoons: a learner-centered approach to comprehending texts, Englısh Teachıng Forum, 28-31.

Öz, M., F. (2001). Uygulamalı Türkçe Öğretimi, Ankara: Anı Yayıncilık.

Özdemir, E.(1987). İ/kokul Öğretmenleri için Türkçe Öğretimi Kılavuzu, İstanbul: İnkılâp Kitabevi.

Özfidan, B. (2017). Right of knowing and using mother tongue: a mixed method study, English Language Teaching, 10(12), 15-23.

Paige, D. and Agpuri-Lavell, T. 2014). Reading fluency in the middle and secondary grades, International Electronic Journal of Elementary Education (IEJEE), 7(1), 83-96

Razon, N. (2007). Okuma güçlükleri, www.aku.egitim.tr adresinden 08.08.2015 tarihinde alınmıştır.

Sağlam, H. I., Besen, T (2015). Investigating classroom teachers' views on age of starting primary school for 60 66 months old children, International Online Journal of Educational Sciences 7(2) 167-169

Sever, S.(2011). Türkçe Öğretimi ve Tam Öğrenme, Ankara: Anı Yayıncilık.

Shea, M. and Ceprano, M. (2017). Reading with understanding: a global expectation, Journal of Inquiry \& Action in Education, 9(1), 48-68.

Tabačková, Z. (2015). Outside the classroom thinking ınside the classroom walls: enhancing students ' critical thinking through reading literary texts, Procedia Social and Behavioral Sciences, 186, $726-731$

Topçuoğlu Ünal, F., Yiğit, A.(2014). Çocuklarda okuma kültürünün oluşmasında ailenin etkisi, International Journal of Language Academy, 2 (4), 308-322.

Topping, K. J. (2014). Paired reading and related methods for improving fluency, International Electronic Journal of Elementary Education (IEJEE), 7(1), 57-70.
Tsvetkova, M. (2017). The speed reading is in disrepute: advantages of slow reading for the information equilibrium, European Journal of Contemporary Education , 6(3), 593-603.

Yamaç, A. (2014). İlkokul dördüncü sınıf düzeyinde bir öğrencinin sesli okuma akıcılığını artırmaya yönelik bir uygulama, K. Ü. Kastamonu Eğitim Dergisi, 23 (2), 631-644.

Yıldız, M., Kızıltaş, Y. (2017). The attitudes of secondary school students toward school and reading: a comparison in terms of mother tongue, Gender and Class Level, IJELS, 6(1), 27-37.

Zhang, Y. (1999). Intertextual dynamics: understanding the reading and inquiry processes of competent readers in a collaborative learning environment, ERIC, 1-47.

Zera, D. A. and Lucian, D. G. 2001). Self-organization and learning disabilities: a theoretical perspective for the Interpretation and understanding of dysfunction, Learning Disability Quarterly, 24(2), 107-118.

Yangın, B.(1999). Dinlediğini Anlama Becerisini Geliştirmede Elves Yönteminin Etkisi, Yayımlanmamış Doktora Tezi, HÜ Sosyal Bilimler Enstitüsü Ankara.

Yangın, B. (2002). Kuramdan Uygulamaya Türkçe Öğretimi, Ankara: Dersal Yayıncılık. 